University of Nebraska - Lincoln

DigitalCommons@University of Nebraska - Lincoln

\title{
Comparison of Broiler Litter and Commercial Fertilizer at Equivalent N Rates on Soil Properties
}

\author{
Ardeshir Adeli \\ USDA-ARS, ardeshir.adeli@ars.usda.gov \\ Haile Tewolde \\ USDA-ARS \\ Karamat Sistani \\ USDA-ARS \\ Dennis Rowe \\ Mississippi State University
}

Follow this and additional works at: https://digitalcommons.unl.edu/usdaarsfacpub

Part of the Agricultural Science Commons

Adeli, Ardeshir; Tewolde, Haile; Sistani, Karamat; and Rowe, Dennis, "Comparison of Broiler Litter and Commercial Fertilizer at Equivalent N Rates on Soil Properties" (2010). Publications from USDA-ARS / UNL Faculty. 511.

https://digitalcommons.unl.edu/usdaarsfacpub/511

This Article is brought to you for free and open access by the U.S. Department of Agriculture: Agricultural Research Service, Lincoln, Nebraska at DigitalCommons@University of Nebraska - Lincoln. It has been accepted for inclusion in Publications from USDA-ARS / UNL Faculty by an authorized administrator of DigitalCommons@University of Nebraska - Lincoln. 


\title{
Comparison of Broiler Litter and Commercial Fertilizer at Equivalent N Rates on Soil Properties
}

\author{
ARDESHIR ADELI, ${ }^{1}$ HAILE TEWOLDE ${ }^{1}$ \\ KARAMAT SISTANI, ${ }^{2}$ AND DENNIS ROWE ${ }^{3}$ \\ ${ }^{1}$ USDA-ARS, Genetic and Precision Agriculture Research Unit, Mississippi \\ State, Starkville, Mississippi, USA \\ ${ }^{2}$ USDA-ARS, Bowling Green, Kentucky, USA \\ ${ }^{3}$ Mississippi State University-Plant and Soil Sciences, Mississippi State, \\ Mississippi, USA
}

\begin{abstract}
A 3-year study was conducted to determine the effects of broiler litter relative to inorganic fertilizer on soil nutrient content and quality in an upland Loring silt loam soil. Treatments included annual broiler litter rates of 0, 2.2, 4.5, 5.6, 6.7, 10.1, and $13.4 \mathrm{Mg} \mathrm{ha} \mathrm{o}^{-1} \mathrm{y}^{-1}$ and commercial fertilizer rates of 34,68, 90,112,134, and $168 \mathrm{~kg}$ nitrogen $(N) h a^{-1} y^{-1}$. Broiler litter application linearly increased soil total carbon $(C)$, microbial biomass $C$, extractable soil phosphorus $(P)$, potassium $(K)$, soil cation exchange capacity $(C E C)$, and the stability of soil aggregate. At the highest broiler litter rate, the stability of soil aggregate was $34 \%$ greater than inorganic fertilizer. Application of broiler litter or fertilizer $N$ at rate greater than $6.7 \mathrm{Mg} \mathrm{ha}^{-1}$ or 90

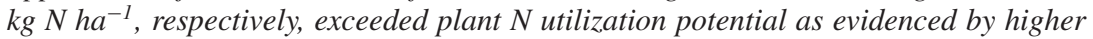
end-of-season soil residual nitrate $\left(\mathrm{NO}_{3}\right)-\mathrm{N}$. Broiler litter is more effective in improving soil physical, chemical, and biological components than conventional fertilizer.
\end{abstract}

Keywords Aggregate stability, biomass C, broiler litter, soil quality, upland soil

\section{Introduction}

Fertilizing crops with inorganic nitrogen $(\mathrm{N})$ sources is believed to benefit soil by increasing soil organic carbon (C) through boosting crop growth and plant residue (Dick 1992) followed by improving soil chemical, physical, and biological properties (Perrott, Sarathchandra, and Dow 1992; Fraser, Haynes and Williams 1994). Some recent studies, however, revealed that long-term $\mathrm{N}$ fertilization depletes soil organic carbon by promoting the decomposition of crop residues and soil organic matter leading to deterioration of soil quality (Khan et al., 2007). Barak et al. (1997) reported that long-term N fertilization decreases levels of exchangeable calcium $(\mathrm{Ca})$, magnesium $(\mathrm{Mg})$, potassium $(\mathrm{K})$, and soil cation exchange capacity (CEC). Regardless of the negative effects of long-term $\mathrm{N}$ fertilization on soil quality, $\mathrm{N}$ has been applied intensively in row crop productions.

As commercial fertilizer $\mathrm{N}$ prices rise, interest in using broiler litter $\mathrm{N}$ as an economical alternative to commercial fertilizer for row crop production has been considered.

Received 6 March 2009; accepted 26 August 2009.

This article not subject to US copyright law.

Address correspondence to Ardeshir Adeli, USDA-ARS, Crop Science Research Laboratory, 810 HWY 12 East, Mississippi State, MS 39759. E-mail: ardeshir.adeli@ars.usda.gov 
Application of litter to cotton (Gossypium hirsutum L.) as an N source has been shown to be an agronomically viable alternative (Reddy, Nyakatawa, and Reeves 2004; Sistani et al. 2004; Tewolde, Sistani, and Rowe 2005; Tewolde et al. 2007). However, in most of the studies, manure was compared with fertilizer as a single recommended rate or fertilizer combined with manure as supplement (Liu et al., 2001; Tewolde et al. 2007). Determining the effects of chemical fertilizer and manure at equivalent $\mathrm{N}$ rate will improve manure management and strengthen crop advisers' confidence in broiler litter nutrient credits, which can lead to minimizing offsite nutrient movement.

Some studies have indicated manure applications improved soil quality compared to chemical fertilizer (Edmeades 2003; Adeli et al. 2007) because manure supplies an additional exogenous source of organic matter, which influences the capacity of soil to store and release nutrients for crop growth during decomposition and mineralization (Lal 2002). Others have shown a decline in soil quality or fertility (Sharpley et al. 1998; A. Kumar and Yadav 2001; Zhang et al. 2002). For example, Sharpley et al. (1998) indicated that long-term application of broiler litter can negatively influence soil productivity and quality by creating potential nutrient imbalance in soil fertility. However, Lu et al. (2001) indicated that fertilization with inorganic $\mathrm{N}$ did not have a significant effect on changes in soil quality. These conflicting reports from both manure and commercial fertilizer justify the necessity for research on the effects of different rates of manure relative to chemical fertilizer at equivalent available $\mathrm{N}$ rate on soil productivity and quality.

In a long-term manure application study on grassland, Christie (1987) reported that manure and fertilizer had similar effects on crop production. In row crops, Mitchell and $\mathrm{Tu}$ (2005) compared three different rates of broiler with commercial fertilizer at equivalent plant available $\mathrm{N}$ for cotton in a silty clay loam and a sandy loam soil and concluded that total $\mathrm{N}$ in litter was as effective as $\mathrm{N}$ from ammonium nitrate for cotton yield. However, the effects of these nutrient management practices on soil quality were not reported. The comparability of broiler litter with fertilizer at equivalent $\mathrm{N}$ rate to cotton on soil quality is lacking in the literature. Most of the work on long-term effects of animal manure on soil productivity and quality has been done on grassland and pasture in Europe and the northern United States (Borghi et al. 1995; Berzsenyi, Gyoreffy, and Lap 2000; Bronick and Lal 2005; Karlen et al. 2006). With recent interest in using broiler litter for row crops in Mississippi, the relative impact of broiler litter and fertilizer on soil nutrient dynamics and properties in the southeastern United States, particularly in Mississippi agro-ecosystems, is lacking in the literature and is not documented. The objective of this study was to determine the effects of broiler litter relative to inorganic fertilizer at equivalent $\mathrm{N}$ rates applied on soil chemical, physical, and biological properties in an upland soil.

\section{Materials and Methods}

This study was conducted at the Mississippi Agricultural and Forestry Experiment Station of Mississippi State University, North Branch near Holly Spring, Mississippi, on a Loring silt loam (fine-silty, mixed, active, thermic Oxyaquic Fragiudalfs) soil from 2002 to 2004. Initial soil samples were taken from the $0-15 \mathrm{~cm}$ depth. Initial soil chemical characteristics are shown in Table 1. The experimental design was randomized complete block with 13 treatments replicated four times. A plot consisted of eight rows spaced $0.97 \mathrm{~m}$ apart and $15.2 \mathrm{~m}$ long. Treatments included broiler litter application of $0,2.2,4.5,5.6,6.7,10.1$, and 13.4 $\mathrm{Mg} \mathrm{ha}^{-1} \mathrm{y}^{-1}$ applied at total $\mathrm{N}$ rates shown in Table 2. Inorganic fertilizer was applied at the rate of $34,68,90,112,135$, and $168 \mathrm{~kg} \mathrm{~N} \mathrm{ha}^{-1} \mathrm{y}^{-1}$. The source of commercial fertilizer $\mathrm{N}$ was $\mathrm{NH}_{4} \mathrm{NO}_{3}$. The field was disked and bedded up each year. In the spring, before 
Table 1

Initial chemical characteristic of the soil at the $0-15 \mathrm{~cm}$ depth

\begin{tabular}{lc}
\hline Parameter & Value \\
\hline $\mathrm{pH}$ & 4.92 \\
Total C $\left(\mathrm{g} \mathrm{kg}^{-1}\right)$ & 10.59 \\
Total N $\left(\mathrm{g} \mathrm{kg}^{-1}\right)$ & 1.14 \\
$\mathrm{NH}_{4}-\mathrm{N}\left(\mathrm{mg} \mathrm{kg}^{-1}\right)$ & 19.0 \\
$\mathrm{NO}_{3}-\mathrm{N}\left(\mathrm{mg} \mathrm{kg}^{-1}\right)$ & 7.04 \\
$\mathrm{M} 3 \mathrm{P}\left(\mathrm{mg} \mathrm{kg}^{-1}\right)$ & 68.9 \\
$\mathrm{WSP}\left(\mathrm{mg} \mathrm{kg}^{-1}\right)$ & 4.2 \\
$\mathrm{~K}\left(\mathrm{~g} \mathrm{~kg}^{-1}\right)$ & 0.23 \\
$\mathrm{Cu}\left(\mathrm{mg} \mathrm{kg}^{-1}\right)$ & 1.09 \\
$\mathrm{Zn}\left(\mathrm{mg} \mathrm{kg}^{-1}\right)$ & 1.82 \\
Bulk density $\left(\mathrm{g} \mathrm{cm}^{-3}\right)$ & 1.36 \\
\hline
\end{tabular}

planting cotton, a commercial fertilizer was broadcast and incorporated over the entire inorganic fertilizer $\mathrm{N}$ plots at the rate of $39 \mathrm{~kg} \mathrm{P} \mathrm{ha}^{-1}$ and $112 \mathrm{~kg} \mathrm{~K} \mathrm{ha}^{-1}$ in 2002 and $34 \mathrm{~kg} \mathrm{P}$ $\mathrm{ha}^{-1}$ and $65 \mathrm{~kg} \mathrm{~K} \mathrm{ha}^{-1}$ in 2004 . The sources of phosphorus $(\mathrm{P})$ and $\mathrm{K}$ fertilizers were triple superphosphate and potassium chloride $(\mathrm{KCl})$, respectively. Before planting cotton, broiler litter and commercial fertilizer $\mathrm{N}$ were applied by hand and incorporated into the soil within 2 days of application. Broiler litter was obtained from a commercial broiler producer in northern Mississippi every year and kept under cover at the research site before application. Broiler litter samples were collected at the time of application for nutrient analyses. Total $\mathrm{N}$ and total $\mathrm{C}$ contents in broiler litter were determined using an automated dry combustion C/N analyzer (model NA 1500 NC; Carlo Erba, Milan, Italy). Total P and other element such as $\mathrm{K}, \mathrm{Ca}, \mathrm{Mg}$, copper $(\mathrm{Cu})$, and zinc $(\mathrm{Zn})$ contents of broiler litter was determined by dry-ashing a 1-g sample according to procedures outlined by Issac and Kerber (1977) and measured using inductively coupled argon plasma spectrophotometry (ICP; Thermo Jarrel Ash; Iris Advantage ICP, 40669, Houghton, Michigan). Chemical analysis of broiler litter and the amount of nutrient applied each year are shown in Tables 2 and 3.

Each year after picking cotton, the cotton stalks were shredded and soil samples from the center of each plot were taken to $90 \mathrm{~cm}$ depth and divided into 0 - to 15-, 15- to 30-, $30-$ to $60-$, and $60-$ to $90-\mathrm{cm}$ increments. Four cores $(2.5 \mathrm{~cm}$ in diameter) were taken, composited for each plot and depth in the field, mixed thoroughly, and a representative subsample was taken for analysis. Soils taken from 0-15 $\mathrm{cm}$ depth were divided into two different bags. One bag was stored at $5{ }^{\circ} \mathrm{C}$ until being analyzed for water content and biological properties. The remaining soil plus the samples taken from other depths were airdried, ground to pass through a 2-mm sieve, and stored at room temperature until analysis.

Measured soil chemical and biological properties included soil $\mathrm{pH}$, total $\mathrm{C}$, total $\mathrm{N}$, Mehlich III extractable P, exchangeable $\mathrm{Ca}, \mathrm{Mg}$, and $\mathrm{K}$, cation exchange capacity (CEC), and microbial biomass $\mathrm{C}$. Soil $\mathrm{pH}$ and electrical conductivity were determined using 0.01 $\mathrm{M}$ calcium chloride $\left(\mathrm{CaCl}_{2}\right)$ on a 1:1 w/w basis and $\mathrm{pH}$ was determined using a glass electrode ( $\mathrm{pH} /$ electrical conductivity (EC)/total dissolved solids (TDS); meter model 19813-0, Hanna, Woonsocket, Rhode Island). Total $\mathrm{C}$ and total $\mathrm{N}$ in the soil were determined for 0-15 cm depth from air-dried, finely ground soil using an automated dry combustion $\mathrm{C} / \mathrm{N}$ analyzer (model NA $1500 \mathrm{NC}$ ). Soil samples were extracted with $2 \mathrm{M} \mathrm{KCl}$ and 


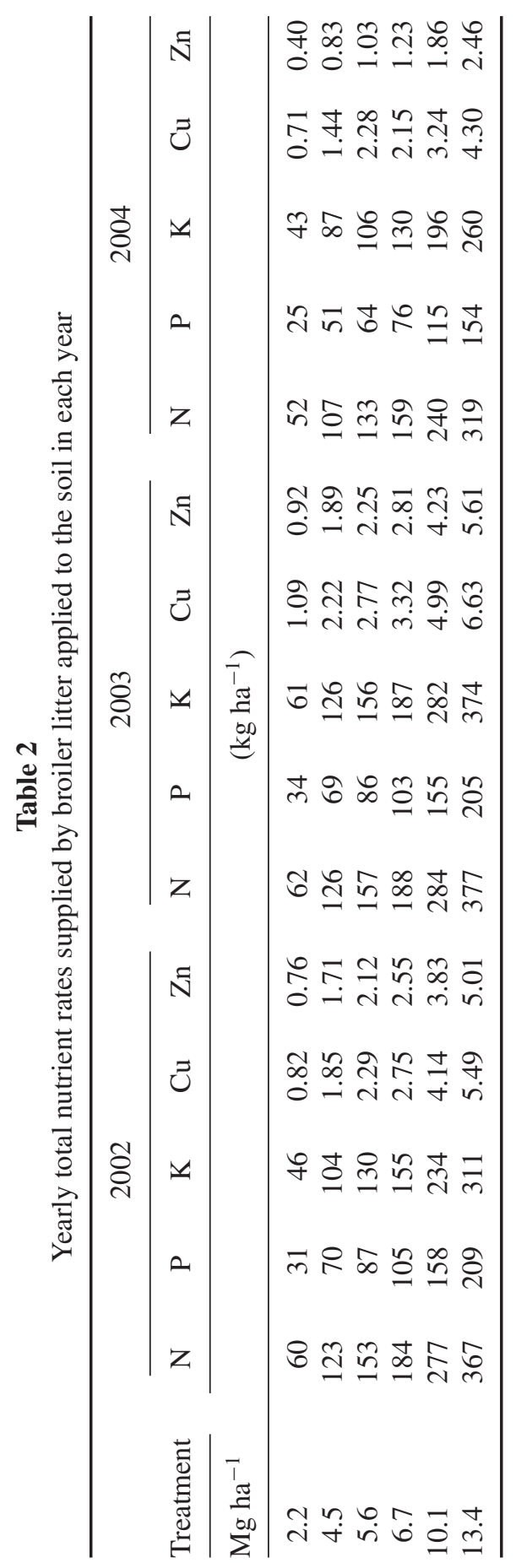


A. Adeli et al.

Table 3

Chemical analysis of broiler litter used in the study

\begin{tabular}{lrrrr}
\hline & 2002 & 2003 & 2004 & Average \\
\hline $\mathrm{pH}$ & 7.03 & 7.2 & 6.9 & 7.04 \\
Total C $\left(\mathrm{g} \mathrm{kg}^{-1}\right)$ & 270 & 331 & 335 & 312 \\
Total N $\left(\mathrm{g} \mathrm{kg}^{-1}\right)$ & 27.4 & 28.1 & 23.8 & 26.4 \\
Total P $\left(\mathrm{g} \mathrm{kg}^{-1}\right)$ & 15.6 & 15.3 & 11.4 & 15.1 \\
$\mathrm{~K}\left(\mathrm{~g} \mathrm{~kg}^{-1}\right)$ & 23.2 & 27.9 & 19.4 & 23.5 \\
$\mathrm{Ca}\left(\mathrm{g} \mathrm{kg}^{-1}\right)$ & 25.3 & 26.2 & 18.7 & 23.4 \\
$\mathrm{Mg}\left(\mathrm{g} \mathrm{kg}^{-1}\right)$ & 5.3 & 5.6 & 3.9 & 4.9 \\
$\mathrm{Cu}\left(\mathrm{mg} \mathrm{kg}^{-1}\right)$ & 409 & 495 & 321 & 408 \\
$\mathrm{Zn}\left(\mathrm{mg} \mathrm{kg}^{-1}\right)$ & 378 & 419 & 184 & 327 \\
\hline
\end{tabular}

inorganic $\mathrm{N}$ (ammonium $\left(\mathrm{NH}_{4}\right)-\mathrm{N}+$ nitrate $\left(\mathrm{NO}_{3}\right)-\mathrm{N}$ ) in the extract were measured using a Lachat instrument (QC 800 flow injection analyzer; Lachat, Loveland, Colorado). Soil $\mathrm{P}$ in Mehlich III extracts was measured using ICP. Soil microbial biomass C (MBC) were determined using the microwave irradiation method (Islam and Weil 1998). Exchangeable $\mathrm{Ca}, \mathrm{Mg}, \mathrm{Na}, \mathrm{K}, \mathrm{Cu}$, and $\mathrm{Zn}$ were determined by displacement with $1 \mathrm{M}$ ammonium acetate at $\mathrm{pH}=7$ and subsequently measured by ICP. Cation Exchange Capacity was determined by summation of exchangeable base cations $\left(\mathrm{Ca}^{+2}, \mathrm{Mg}^{+2}, \mathrm{~K}^{+1}\right.$, and $\mathrm{Na}^{+1}$ ) (Warncke and Brown 1998). Soil bulk density and stability of soil aggregate was determined in soil samples taken at the beginning (2002) as initial soil samples and at the end of growing season of the third year. Soil bulk density was determined using a procedure described by Grossman and Reinsch (2002). A typical double-cylinder, hammer-driven core sampler was used for obtaining soil samples for bulk density. A $15-\mathrm{cm}$ ring was placed inside the sampler, inserted by force into the top $0-15 \mathrm{~cm}$ depth, and the whole core was taken. Samples were trimmed from the top and bottom of the ring, weighed, and oven-dried at $105{ }^{\circ} \mathrm{C}$. The volume of the soil was calculated based on the dimension of the ring. Soil bulk density was calculated by dividing the mass of soil by the volume. Soil aggregate stability was determined on 2-mm sieved air-dried soil by a modified turbidimetric method (Williams et al. 1966).

The general linear model (GLM) procedure in SAS (SAS Institute 1996) was used to perform an analysis of variance (ANOVA). Data were analyzed using a simple regression model, which included linear and quadratic trends. ANOVA using single degree of freedom comparisons was performed to contrast fertilizer against broiler litter for all measured variables. All differences mentioned in the discussion are significant at $P \leq 0.05$ unless stated otherwise.

\section{Results and Discussion}

\section{Soil pH}

Averaged across years, surface soil $\mathrm{pH}$ slightly decreased with increasing inorganic fertilizer $\mathrm{N}$ rates (Table 4). Broiler litter application had the opposite effect with increasing litter rate increasing soil $\mathrm{pH}$. At the highest rate $\left(13.4 \mathrm{Mg} \mathrm{ha}^{-1}\right)$ broiler litter increased soil $\mathrm{pH}$ by 0.45 compared to the control (Table 4$)$. Hue (1992) reported that broiler litter contains 


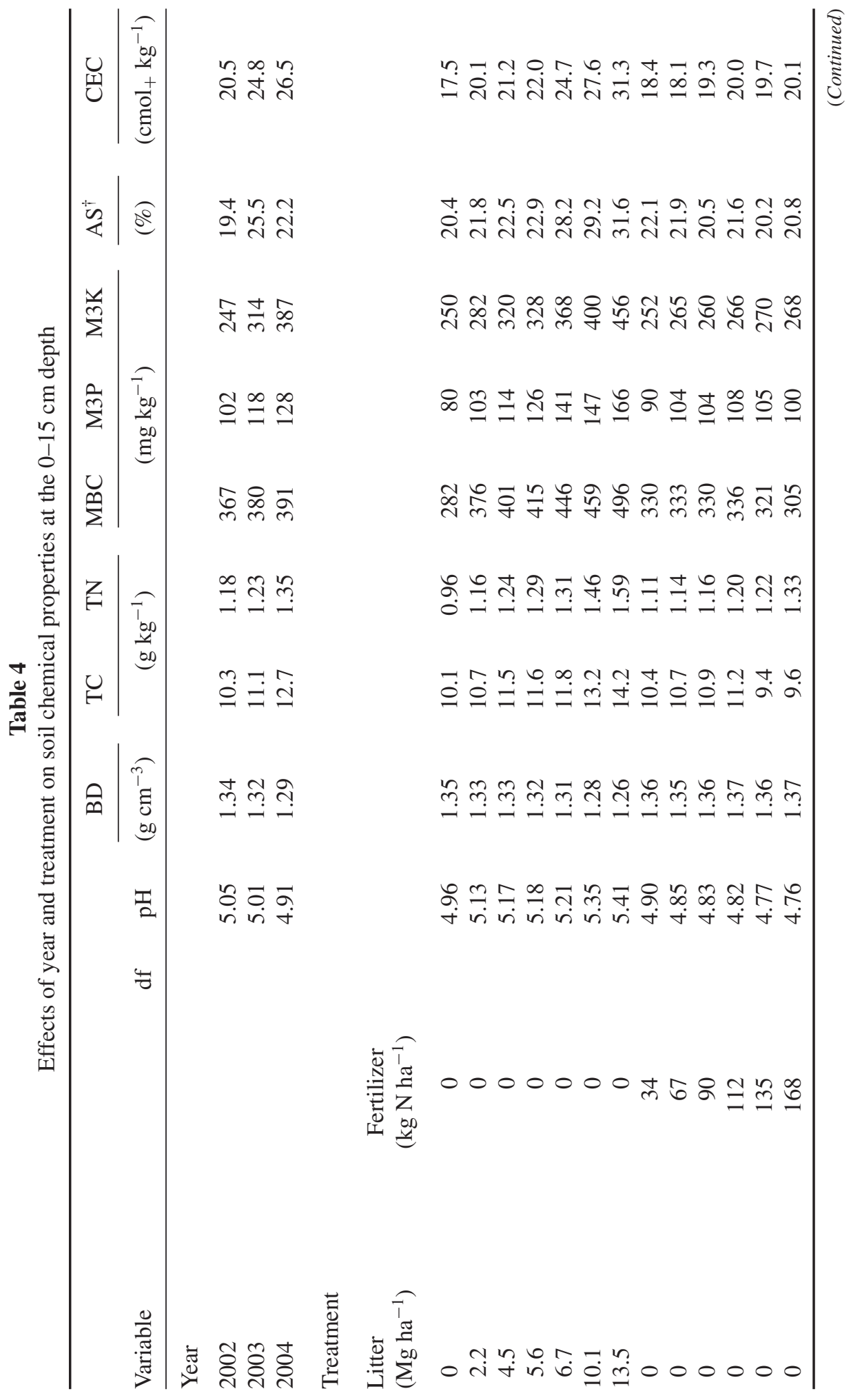




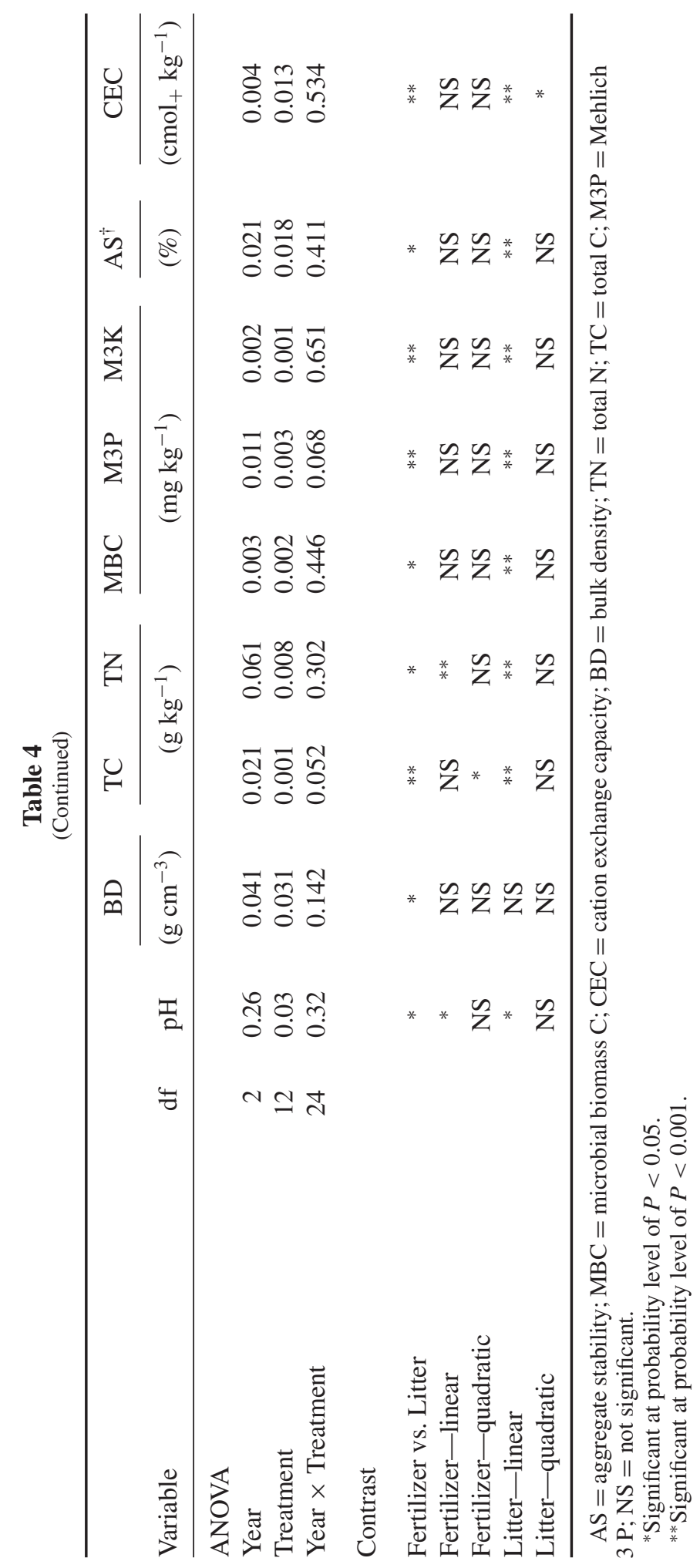


$\mathrm{CaCO}_{3}$ (added in the diet as source of calcium) that will maintain or increase soil $\mathrm{pH}$ when applied to a low-pH soil. Our results are in agreement with Mokolobate and Haynes (2002), who reported in the case of low-pH soils $(<5.0)$ such as our soil that the addition of any organic residue would increase soil $\mathrm{pH}$. Inorganic fertilizer $\mathrm{N}$ at the highest $\mathrm{N}$ rate (168 $\mathrm{kg} \mathrm{N} \mathrm{ha}^{-1}$ ) reduced soil $\mathrm{pH}$ by 0.20 units (from 4.96 [original level] to 4.76 ) after 3 years of annual applications. Our results correspond with the work by Mitchell and Tu (2006), who reported that long-term application of ammonium nitrate to cotton in a Coastal Plain soil resulted in decreasing soil $\mathrm{pH}$ by 0.1 to 1.0 units as $\mathrm{N}$ rate of ammonium nitrate increased from 67 to $269 \mathrm{~kg} \mathrm{ha}^{-1}$. Declining $\mathrm{pH}$ with inorganic fertilizer was likely due to the acidifying effects of the long-term addition of $\mathrm{N}$ fertilizer (Bowman and Halvorson 1998). The acidifying effects of inorganic fertilizer are related to the proton $(\mathrm{H}+)$ production during nitrification of ammoniacal fertilizer (Adams 1984) compared with the liming effects of broiler litter produced by birds fed rations with mineral supplements (Hue 1992).

\section{Bulk Density and Aggregate Stability}

Applying commercial fertilizer did not affect bulk density. Soil bulk density was unaffected at the lower rates of broiler litter applications because the amount of organic matter applied to this silt loam soil, with original organic matter content of $10.59 \mathrm{~g} \mathrm{~kg}^{-1}$, was not enough to make a significant difference in soil bulk density. However, at a rate greater than 6.7 $\mathrm{Mg} \mathrm{ha}^{-1}$, broiler litter application significantly decreased soil bulk density. For example, at the highest broiler litter rate $\left(13.4 \mathrm{Mg} \mathrm{ha}^{-1}\right)$, soil bulk density decreased by $7 \%$ compared to the control (from 1.35 to $1.26 \mathrm{~g} \mathrm{~cm}^{-3}$; Table 4). The stability of aggregate was not influenced by inorganic fertilizer $\mathrm{N}$ applications. However, broiler litter applications linearly increased soil aggregate stability (Table 4). The positive effect of broiler litter application on the stability of aggregate could be related to an increased total $\mathrm{C}$ in the soil (Table 4), which would increase biological activities and soil fungal population (Pratt and Tewolde 2008), which produce more organic binding or stabilizing agents for soil macroaggregate formation followed by soil quality improvement (Angers, Pesant, and Vignaux 1992).

\section{Soil Total C and Microbial Biomass $C$}

Averaged across broiler litter and inorganic fertilizer $\mathrm{N}$ application rate, soil total $\mathrm{C}$ increased with increasing year of application (Table 4), indicating the cumulative effects of broiler litter on soil C. Because the Year $\times$ Treatment interaction was significant (Table 4), soil total $\mathrm{C}$ concentration was presented for each year. Fertilizer $\mathrm{N}$ applications affected soil $\mathrm{C}$ in a quadratic fashion (Figure 1). Although increasing fertilizer $\mathrm{N}$ is expected to benefit soil C by increasing plant biomass (Dick 1992), inorganic fertilizer $\mathrm{N}$ at rates greater than $90 \mathrm{~kg} \mathrm{~N} \mathrm{ha}^{-1}$ declined soil total $\mathrm{C}$ content and the trend was consistent in each year (Figure 1). For example, in 2004, fertilizer $\mathrm{N}$ at the highest rate $\left(168 \mathrm{~kg} \mathrm{~N} \mathrm{ha}^{-1}\right)$ decreased total soil $\mathrm{C}$ by $10 \%$ compared to the rate of $90 \mathrm{~kg} \mathrm{~N} \mathrm{ha}^{-1}$ (from 11.65 to $10.50 \mathrm{~g} \mathrm{~kg}^{-1}$ ). Our results are in agreement with work by Khan et al. (2007), who reported that longterm $\mathrm{N}$ fertilization depleted soil organic carbon by promoting the decomposition of crop residues and soil organic matter.

Broiler litter application was more effective in increasing soil $\mathrm{C}$ than inorganic fertilizer. In each year, total $\mathrm{C}$ at the 0 to $15 \mathrm{~cm}$ soil depth linearly increased with increasing broiler litter rate and ranged from $9.4 \mathrm{~g} \mathrm{~kg}^{-1}$ for the control to $16.9 \mathrm{~g} \mathrm{~kg}^{-1}$ for the highest 

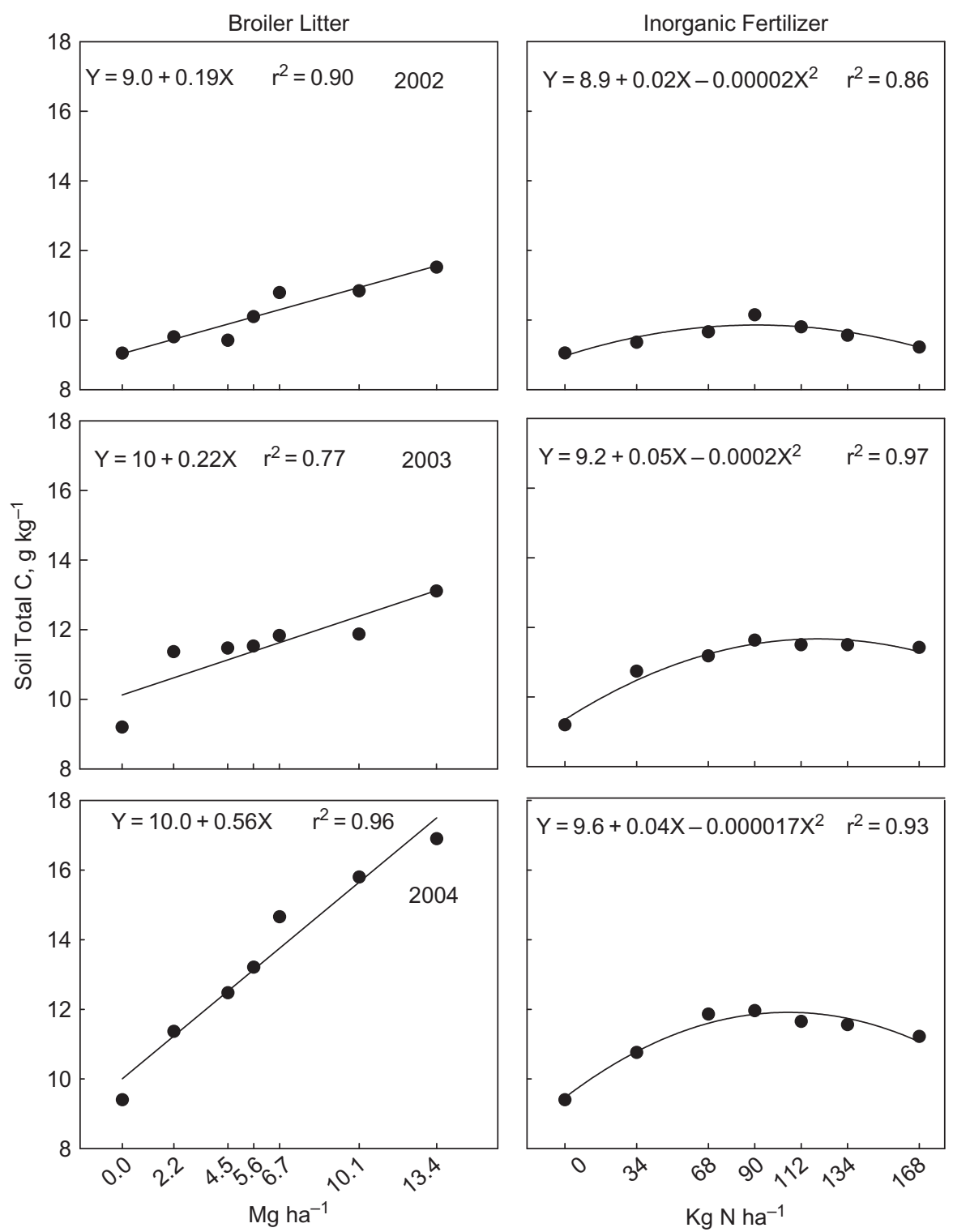

Figure 1. Effects of broiler litter relative to inorganic fertilizer $N$ on soil total $C$ at the $0-15 \mathrm{~cm}$ depth.

broiler litter rate (13.4 $\mathrm{Mg} \mathrm{ha}^{-1}$; Figure 1). The effect of broiler litter on soil C increased with increasing years of application as evidenced by increasing the slope of regression lines ranged from 0.19 in 2002 to 0.56 in 2004 (Figure 1). The greater total soil C with broiler litter than inorganic fertilizer is related to the addition of higher residue or $\mathrm{C}$ from broiler litter (Table 3). Similarly, K. Kumar, Sing, and Walia (2000) observed significantly higher $\mathrm{C}$ contents in soil receiving manure than plots treated with only inorganic fertilizer. The effects of broiler litter relative to fertilizer $\mathrm{N}$ rates on microbial biomass $\mathrm{C}$ followed a 
similar pattern as soil total C (Table 4). Averaged across years, microbial biomass $\mathrm{C}$ was increased with increasing broiler litter application (Table 4). The effects of broiler litter fertilization on microbial biomass $\mathrm{C}$ were significantly greater than inorganic fertilizer $\mathrm{N}$ (Table 4). Increases in microbial biomass $\mathrm{C}$ with increasing broiler litter can be related to the quantity of C substrates (Islam and Weil 2000), which is greater in soils collected from plots receiving broiler litter than those from inorganic fertilizer. This indicates that $\mathrm{C}$ is a limiting factor for development of soil microbial activity. Our results are consistent with other reports that have shown that soils receiving animal manures have a larger microbial biomass $\mathrm{C}$ than the same soils receiving only chemical fertilizers (Wienhold 2005).

\section{Soil Total $\mathrm{N}$ and Residual $\mathrm{NO}_{3}-\mathrm{N}$}

Total $\mathrm{N}$ at the 0 to $15 \mathrm{~cm}$ soil depth linearly increased with increasing both broiler litter and fertilizer applications (Table 4). The effect of broiler litter application on soil total $\mathrm{N}$ was greater than inorganic fertilizer. For example, averaged across years, total $\mathrm{N}$ was $16 \%$ greater for broiler litter at the highest rate $\left(13.4 \mathrm{Mg} \mathrm{ha}^{-1}\right)$ than inorganic fertilizer at $168 \mathrm{~kg} \mathrm{~N} \mathrm{ha}^{-1}$ (1.59 vs. $1.33 \mathrm{~g} \mathrm{~kg}^{-1}$, respectively; Table 4).

Residual $\mathrm{NO}_{3}-\mathrm{N}$ concentrations in the soil profile where broiler litter and commercial fertilizer were applied in each year are shown in Table 5. In 2003, the concentration of soil residual $\mathrm{NO}_{3}-\mathrm{N}$ for both $\mathrm{N}$ sources was not only greater than those in 2002 and 2004 but its concentration was higher in deeper soil increments (Table 5). This could possibly be related to the weather condition. The year 2003 was an unusual growing season, with a cool and wet spring followed by an extended period of drought and then ending with a wet late summer and fall (Table 6). This condition delayed litter application until the last day of May and cotton was planted on 2 June. The drought condition in July and August when the plants were fruiting might result in less $\mathrm{N}$ utilization followed by $\mathrm{NO}_{3}-\mathrm{N}$ accumulation in the soil profile (Table 5). In 2003, greater amounts of rain in late summer and fall (Table 6) increased the potential of leaching $\mathrm{NO}_{3}-\mathrm{N}$ beyond the root zone as evidenced by increasing $\mathrm{NO}_{3}-\mathrm{N}$ concentrations in deeper soil increments (Table 5). Averaged across depth in each year, application of broiler litter and chemical fertilizer increased nitrate $\mathrm{N}$ concentration in the soil. Although broiler litter and fertilizer $\mathrm{N}$ were applied at equivalent available $\mathrm{N}$, soil $\mathrm{NO}_{3}-\mathrm{N}$ concentration was much greater for commercial fertilizer than broiler litter (Table 5). This might possibly be related to lower available $\mathrm{N}$ during the cotton growing season from applied broiler litter as predicted. In 2004, application of broiler litter and commercial fertilizer at rates greater than $6.7 \mathrm{Mg} \mathrm{ha}^{-1}$ and $90 \mathrm{~kg} \mathrm{~N} \mathrm{ha}^{-1}$, respectively, exceeded crop $\mathrm{N}$ utilization potential as evidenced by increasing soil nitrate $\mathrm{N}$ concentrations (Figure 2). The accuracy of this pattern was confirmed by Tewolde et al. (2010), who reported no yield advantage from broiler litter and commercial fertilizer at rates greater than $6.7 \mathrm{Mg} \mathrm{ha}^{-1}$ or $90 \mathrm{~kg} \mathrm{~N} \mathrm{ha}^{-1}$, respectively, at the same study site.

\section{Soil K, $P$, and CEC}

Averaged across years, $\mathrm{K}$ concentration in the surface soil $(0-15 \mathrm{~cm})$ linearly increased with increasing broiler litter applications (Table 4). This indicates the buildup of $\mathrm{K}$ in the soil when broiler litter is applied based on $\mathrm{N}$ needs of crops. Commercial fertilizer did not significantly increase soil $\mathrm{K}$.

Soil CEC at the $0-15 \mathrm{~cm}$ depth linearly increased with increasing broiler litter applications and ranged from $17.5 \mathrm{cmol}_{+} \mathrm{kg}^{-1}$ for the control to $31.3 \mathrm{cmol}_{+} \mathrm{kg}^{-1}$ for broiler litter 
at the highest rate of $13.4 \mathrm{Mg} \mathrm{ha}^{-1}$ (Table 4). Commercial fertilizer $\mathrm{N}$ applications did not have a significant effect on soil CEC compared to the control (Table 4). Our results are in agreement with the work of Gao and Chang (1996), who reported that soil CEC increased with increasing manure application.

Table 5

Effects of broiler litter application and inorganic fertilizer $\mathrm{N}$ on soil $\mathrm{NO}_{3}-\mathrm{N}$ concentrations

\begin{tabular}{|c|c|c|c|c|}
\hline & & 2002 & 2003 & 2004 \\
\hline & & \multicolumn{3}{|c|}{$\left(\mathrm{mg} \mathrm{kg}^{-1}\right)$} \\
\hline $0-15$ & & 7.23 & 26.58 & 14.81 \\
\hline $15-30$ & & 15.55 & 41.07 & 15.63 \\
\hline $30-60$ & & 17.1 & 46.69 & 17.04 \\
\hline 60-90 & & 12.2 & 50.4 & 13.4 \\
\hline $\operatorname{LSD}_{(0.05)}$ & & 3.23 & 3.8 & 1.21 \\
\hline $\begin{array}{l}\text { Broiler litter } \\
\left(\mathrm{Mg} \mathrm{ha}^{-1}\right)\end{array}$ & $\begin{array}{l}\text { Fertilizer } \\
\left(\mathrm{kg} \mathrm{N} \mathrm{ha}^{-1}\right)\end{array}$ & & & \\
\hline 0 & 0 & 11.84 & 11.55 & 9.12 \\
\hline 2.2 & 0 & 12.54 & 13.67 & 9.62 \\
\hline 4.5 & 0 & 13.94 & 16.54 & 11.30 \\
\hline 5.6 & 0 & 14.76 & 16.61 & 11.65 \\
\hline 6.7 & 0 & 21.55 & 42.94 & 14.99 \\
\hline 10.1 & 0 & 27.30 & 51.87 & 16.05 \\
\hline 13.4 & 0 & 39.23 & 66.23 & 20.23 \\
\hline 0 & 34 & 14.50 & 15.67 & 10.71 \\
\hline 0 & 68 & 17.39 & 21.05 & 17.27 \\
\hline 0 & 90 & 19.39 & 38.26 & 21.65 \\
\hline 0 & 112 & 28.15 & 61.41 & 32.20 \\
\hline 0 & 134 & 36.04 & 86.50 & 39.84 \\
\hline 0 & 168 & 44.03 & 98.36 & 48.6 \\
\hline \multicolumn{5}{|l|}{ ANOVA } \\
\hline Depth & & 0.016 & 0.003 & 0.034 \\
\hline Treatment & & 0.001 & 0.001 & 0.001 \\
\hline Depth $\times$ Treatment & & 0.272 & 0.071 & 0.094 \\
\hline \multicolumn{5}{|l|}{ Contrast } \\
\hline Fertilizer vs. Litter & & $* *$ & $* *$ & $* *$ \\
\hline Fertilizer-linear & & $*$ & $* *$ & $*$ \\
\hline Fertilizer-quadratic & & * & $* *$ & $* *$ \\
\hline Litter-linear & & $*$ & $* *$ & $*$ \\
\hline Litter-quadratic & & $* *$ & $* *$ & * \\
\hline
\end{tabular}

* Significant at probability level of $P<0.05$.

** Significant at probability level of $P<0.001$. 
Table 6

Monthly total rainfall during the cotton growing season in 2002 to 2004, Holly Springs, Mississippi

\begin{tabular}{lrrrr}
\hline & \multicolumn{3}{c}{ Rainfall } \\
\cline { 2 - 5 } & 2002 & 2003 & 2004 & 30-Year average \\
\cline { 2 - 5 } Month & & & $(\mathrm{mm})$ & \\
\hline March & 254 & 79 & 103 & 142 \\
April & 32 & 81 & 133 & 138 \\
May & 264 & 289 & 201 & 140 \\
June & 65 & 109 & 154 & 123 \\
July & 87 & 100 & 108 & 109 \\
August & 98 & 40 & 54 & 83 \\
September & 197 & 120 & 62 & 90 \\
October & 244 & 110 & 168 & 110 \\
\hline
\end{tabular}

In each year, the $\mathrm{P}$ concentration in the surface soil $(0-15 \mathrm{~cm})$ increased with broiler litter application (Figure 3). In each year, regression analysis indicated a linear relationship between broiler litter application and soil $\mathrm{P}$ concentration in the surface soil (Figure 3). Increased soil $\mathrm{P}$ concentration from broiler litter is related to the loading rate for both sources in each year. For example, after 3 years, a total of $568 \mathrm{~kg} \mathrm{P}$ $\mathrm{ha}^{-1}$ was applied at the highest rate of $13.4 \mathrm{Mg} \mathrm{ha}^{-1}$ broiler litter, but this value was $107 \mathrm{~kg} \mathrm{P} \mathrm{ha}^{-1}$ for commercial fertilizer at the recommended rate as determined by the Mississippi Soil Testing Laboratory. Similar to K, broiler litter application based on the $\mathrm{N}$ needs of crops resulted in a buildup of soil P. Although approximately $34 \mathrm{~kg} \mathrm{P} \mathrm{ha}^{-1}$ was applied to the $\mathrm{N}$-fertilized plot every year, soil $\mathrm{P}$ concentration was not significantly affected, indicating that $\mathrm{N}$ fertilization either resulted in $\mathrm{P}$ removal or inactivated soil P.

\section{Conclusions}

Application of broiler litter for cotton linearly increased soil total C, microbial biomass C, soil total N, and Mehlich $3 \mathrm{P}$ concentration at the $0-15 \mathrm{~cm}$ soil depth. However, this pattern was not obtained for commercial fertilizer application at the equivalent $\mathrm{N}$ rate. Broiler litter application reduced soil bulk density and increased the stability of soil aggregate compared to the inorganic fertilizer N. Application of broiler litter and inorganic fertilizer $\mathrm{N}$ at a rate greater than $6.7 \mathrm{Mg} \mathrm{ha}^{-1}$ or $90 \mathrm{~kg} \mathrm{~N}^{-1}$ exceeded plant $\mathrm{N}$ utilization potential as evidenced by residual $\mathrm{NO}_{3}-\mathrm{N}$ accumulation in the soil surface. This study indicated that broiler litter is more effective in improving soil property components than conventional fertilizer. As fertilizer $\mathrm{N}$ prices rise, if the costs of transporting and applying broiler litter to agricultural lands can be kept low, producers may benefit by reducing the amount of inorganic fertilizer applied to their cotton lands while improving soil quality status. 

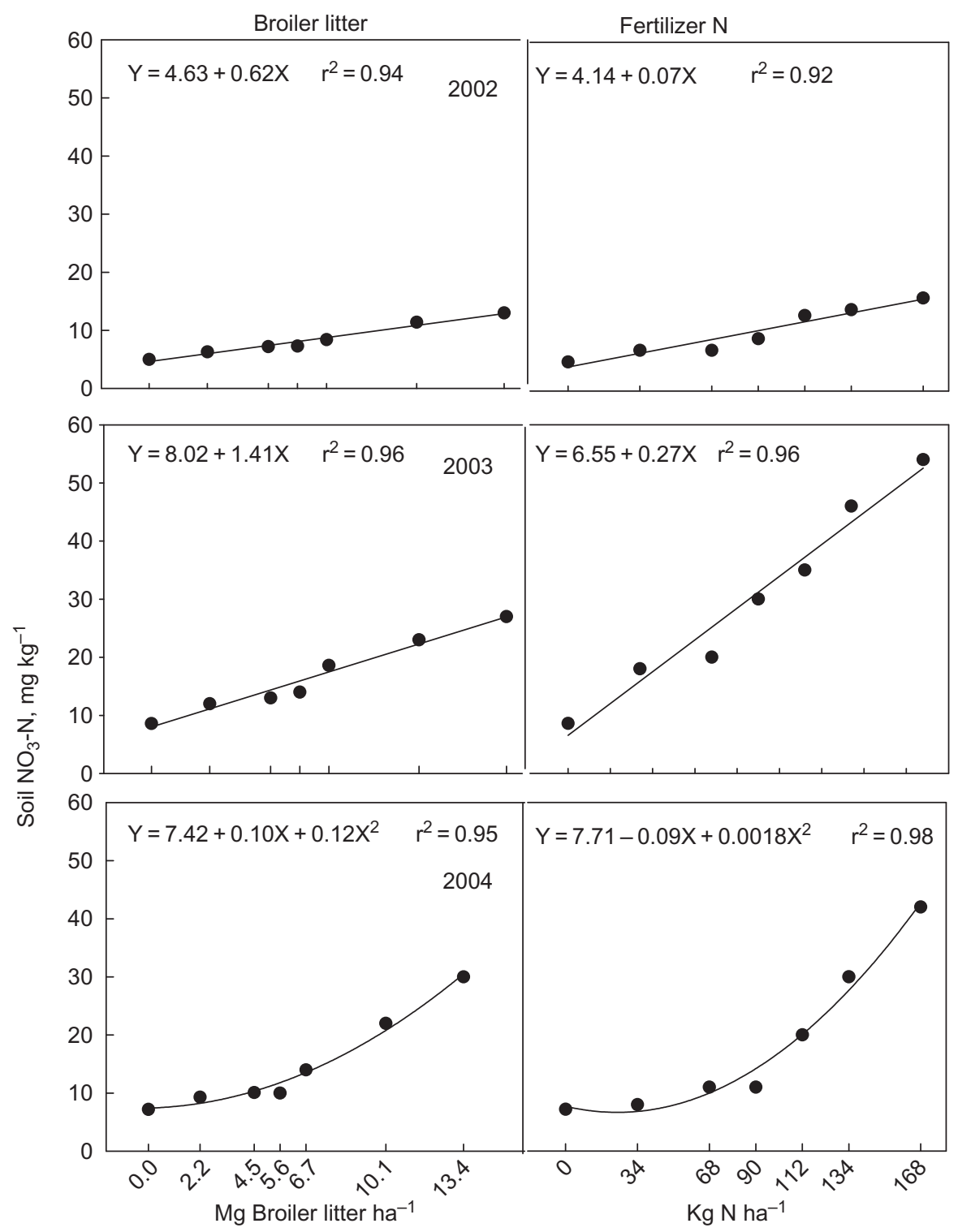

Figure 2. Effects of broiler litter relative to inorganic fertilizer $\mathrm{N}$ on soil residual $\mathrm{NO}_{3}-\mathrm{N}$ at the 0-15 cm depth.

\section{Acknowledgments}

USDA-ARS, Genetics and Precision Agriculture Research Unit, P.O. Box 5367, Mississippi State, MS 39762. Journal article no. J-11509 of the Mississippi Agricultural and Forestry Experiment Station. This work was prepared by employees of the U.S. government as part of their official duties and is in the public domain and may be used without further permission. 


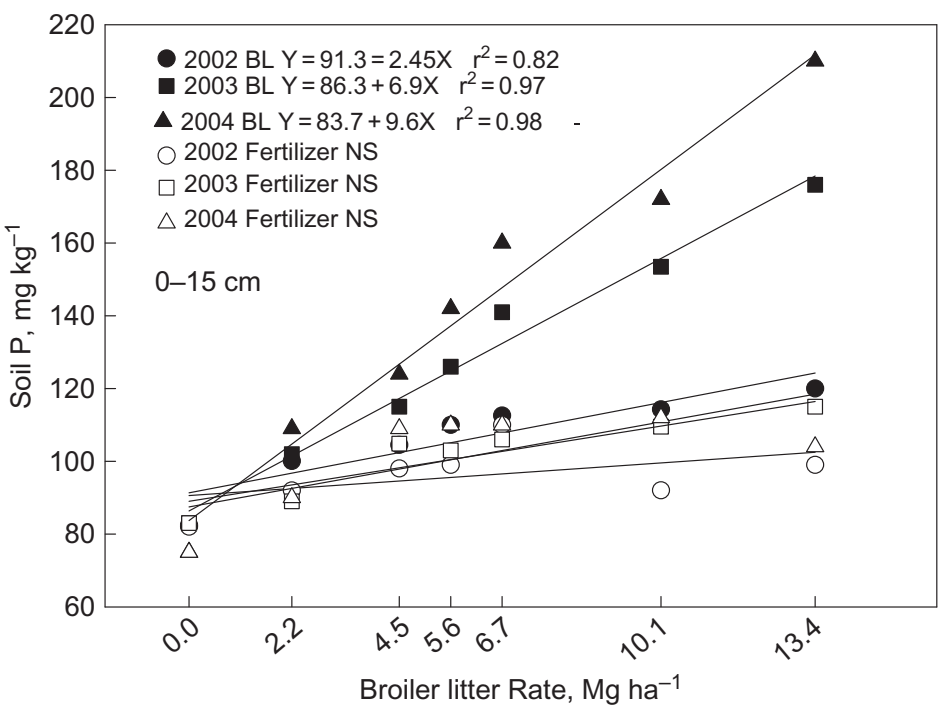

Figure 3. Effects of broiler litter relative to inorganic fertilizer $\mathrm{N}$ on soil Mehlich 3 extractable $\mathrm{P}$ at the $0-15 \mathrm{~cm}$ depth.

\section{References}

Adams, F. 1984. Crop response to lime in the southern United States. In Soil acidity and liming, 2nd ed., ed. F. Adams, 211-265. Madison, WI: American Society of Agronomy, Inc., CSSA, and Soil Science Society of America, Inc. Agron. Monogr. No. 12.

Adeli, A., K. R. Sistani, D. E. Rowe, and H. Tewolde. 2007. Effects of broiler litter applied to no-till and tillage cotton on selected soil properties. Soil Science Society of America Journal 71:974-983.

Angers, D. A., A. Pesant, and J. Vignaux. 1992. Early cropping induced changes in soil aggregation, organic matter, and microbial biomass. Soil Science Society of America Journal 56: 115-119.

Barak, P., B. O. Jobe, A. R. Krueger, I. A. Peterson, and D. A. Laird. 1997. Effects of long-term soil acidification due to nitrogen fertilizer inputs in Wisconsin. Plant Soil 197:61-69.

Berzsenyi, Z., B. Gyoreffy, and D. Lap. 2000. Effect of crop rotation and fertilization on maize and wheat yields and yield stability in a long-term experiment. European Journal of Agronomy 13 (2/3):225-244.

Borghi, B., G. Giordani, M. Corbellini, P. Vaccino, M. Guermandi, and G. Toderi. 1995. Influence of crop rotation, manure and fertilizers on bread making quality of wheat (Triticum aestivum L.). European Journal of Agronomy 4 (1):37-45.

Bowman, R. A., and A. D. Halvorson. 1998. Soil chemical changes after nine years of differential N fertilization in a no-till dryland wheat-corn-fallow rotation. Soil Science 63:241-247.

Bronick, C. J. and R. Lal. 2005. Manuring and rotation effects on soil organic carbon concentration for different aggregate size fractions on two soils in northeastern Ohio. Soil \& Tillage Research 81:239-252.

Christie, P. 1987. Some long term effects of slurry on grassland. Journal of Agricultural Science 108:529-541.

Dick, R. P. 1992. A review: Long term effects of agricultural system on soils biochemical and microbial parameters. Agriculture, Ecosystems \& Environment 40:25-36.

Edmeades, D. C. 2003. Long-term effects of manures and fertilizers on soil productivity and quality: A review. Nutrient Cycling in Agroecosystems 66:165-180. 
Fraser, P. M., R. J. Haynes, and P. H. Williams. 1994. Effects of pasture improvement and cultivation on microbial biomass, enzyme activity and composition and size of earthworm populations. Biology and Fertility of Soils 17:185-190.

Gao, G., and C. Chang. 1996. Changes in CEC and particle size distribution of soils associated with long-term annual application of cattle feedlot manure. Soil Science 161 (2):115-120.

Grossman, R. B., and T. G. Reinsch. 2002. Soil bulk density measurement. In Methods of soil analysis, part 4-Physical methods, eds. J. H. Dane and G. C. Topp, 201-229. Madison, WI: Soil Science Society of America, Inc.

Hue, N. V. 1992. Correcting soil acidity of a highly weathered Ultisol with chicken manure and sewage sludge. Communications in Soil Science and Plant Analysis 23:241-264.

Isaac, R. A., and J. D. Kerber. 1977. Atomic absorption and flame photometry: Techniques and uses in soil, plant, and water analysis. In Instrumental methods for analysis of soils and plant issue, ed. L. M. Walsh, 17-37. Madison, WI: Soil Science Society of America, Inc.

Islam, K. R., and R. R. Weil. 1998. Microwave irradiation of soil for routine measurement of microbial biomass carbon. Biology and Fertility of Soils 27 (4):408-416.

Islam, K. R., and R. R. Weil. 2000. Soil quality indicator properties in mid-Atlantic soils influenced by conservation management. Journal of Soil and Water Conservation 55:69-78.

Karlen, D. L., E. G. Hurley, S. S. Andrews, C. A. Cambardella, D. W. Meek, M. D. Duffy, and A. P. Mallarino. 2006. Crop rotation effects on soil quality at three northern corn/soybean belt locations. Agronomy Journal 98:484-495.

Khan, S. A., R. L. Mulvaney, T. R. Ellsworth, and C. W. Boast. 2007. The myth of nitrogen fertilization for soil carbon sequestration. Journal of Environmental Quality 36:1821-1832.

Kumar, A., and D. S. Yadav. 2001. Long-term effect of fertilizers on the soil fertility and productivity of a rice-wheat system. Journal of Agronomy and Crop Science 186:47-54.

Kumar, K., G. Singh, and S. S. Walia. 2000. Long-term effect of manures and fertilizer on rice yield and soil fertility status in rice wheat system. Environment and Ecology 18:546-549.

Lal, R. 2002. Why carbon sequestration in soils. In Agricultural practices and policies for carbon sequestration in soil, eds. J. M. Kimble, R. Lal, and R. F. Follett, 21-29. Boca Raton, FL: CRC Press.

Liu, H., D. Wang, S. Wang, K. Meng, X. Han, L. Zhang, and S. Shen. 2001. Changes of crop yield and soil fertility under long-term application of fertilizer and recycled nutrients in manure on a black soil. Chinese Journal of Applied Ecology 12:43-46.

Lu, J., Y. Zhang, X. Wang, G. Zhao, and C. Zhang. 2001. Effect of long-term application of chemical fertilizer on soil properties and crop yield. Chinese Journal of Applied Ecology 12:569-572.

Mitchell, C. C., and S. Tu. 2005. Long term evaluation of poultry manure as a source of nitrogen for cotton and corn. Agronomy Journal 97:399-407.

Mitchell, C. C., and S. Tu. 2006. Nutrient accumulation and movement from poultry litter. Soil Science Society of America Journal 70:2146-2153.

Mokolobate, M. S., and R. J. Haynes. 2002. Comparative liming effect of four organic residues applied to an acid soil. Biology and Fertility of Soils 35:79-85.

Perrott, K. W., S. U. Sarathchandra, and B. W. Dow. 1992. Seasonal and fertilizer effects on the organic cycle and microbial biomass in a hill country soil under pasture. Soil Biology and Biochemistry 30:383-394.

Pratt, R. G., and H. Tewolde. 2009. Fungal population levels in soils of cotton fields fertilized with poultry litter and their relationships to soil nutrient concentrations and plant growth parameters. Applied Soil Ecology, 41:41-49.

Reddy, C. K., E. Z. Nyakatawa, and D. W. Reeves. 2004. Tillage and poultry application effects on cotton growth and yield. Agronomy Journal 96:1641-1650.

SAS Institute. 1996. SAS user's guide, ver. 5. Cary, NC: SAS Institute.

Sharpley, A. N., J. J. Meisinger, A. Breeuwsma, T. Sims, T. C. Daniel, and J. S. Schepers. 1998. Impact of animal manure management on ground and surface water quality. In Effective management of animal waste as a soil resource, ed. J. Hatfield, 173-242. Boca Raton, FL: Lewis Publications. 
Sistani, K. R., D. E. Rowe, J. Johnson, and H. Tewolde. 2004. Supplemental nitrogen effect on broiler-litter-fertilized cotton. Agronomy Journal 96:806-811.

Tewolde, H., A. Adeli, K. R. Sistani, D. E. Rowe, and J. R. Johnson. 2010. Equivalency of broiler litter to ammonium nitrate as a cotton fertilizer in an upland soil. Agronomy Journal 102:251-257.

Tewolde, H., K. R. Sistani, and D. E. Rowe. 2005. Broiler litter as a micronutrient source for cotton: Concentration in plant parts. Journal of Environmental Quality 34:1697-1706.

Tewolde, H., K. R. Sistani, D. E. Rowe, A. Adeli, and J. R. Johnson. 2007. Lint yield and fiber quality of cotton fertilized with broiler litter. Agronomy Journal 99:184-194.

Warncke, D., and J. R. Brown. 1998. Potassium and other basic cations. In Recommended chemical soil test procedures for the North Central Region, ed., J. R. Brown, 31-33. North Central Regional Res. Publ. No 221. Missouri Agricultural Experiment Station. SB 1001.

Wienhold, B. J. 2005. Changes in soil attributes following low phosphorus swine slurry application to no-tillage sorghum. Soil Science Society of America Journal 69:206-214.

Williams, B. G., D. J. Greenland, G. R. Lindstrom, and P. Quik. 1966. Techniques for determination of the stability of soil aggregates. Soil Science 101:157-163.

Zhang, F., S. Zhang, B. Zhao, and X. Li. 2002. Evolution of soil fertility and fertilizer benefits under different soil types and cropping systems. Plant Nutrition and Fertilizer Science 8:9-15. 